\title{
Truth telling in Australia's historical narrative
}

\section{Iva Mencevska}

University of Technology Sydney, Faculty of Arts and Social Sciences, PO Box 123, Ultimo NSW 2007, Australia. iva.mencevska@student.uts.edu.au

\begin{abstract}
As it stands, the Australian narrative solely reflects the truth of the European settler with little acknowledgement of the truths of First Nations people. In light of Australia's most recent truth telling project, this essay explores various truth telling projects throughout Australian history, their impact on the national narrative and critically examines the political goal of reconciliation.
\end{abstract}

Key words: truth telling; reconciliation; history; national narrative

\section{Introduction}

History is fundamental in both the construction of a national identity and in making sense of the present, nevertheless it is selective and under consistent revision (Damousi 2002). Australia's historical narrative traditionally begins with the arrival of Captain James Cook in (what came to be known as) Botany Bay in 1770 (Nugent 2008). The narrative that follows lacks acknowledgement of the historical experiences of First Nations people and offers society a simplistic understanding of a seemingly linear series of events on the 'history of European society in Australia' (Attwood 1994, p. 121). For the most part, Australian history has repressed the historical truths of Indigenous Australians and consequently invalidated their experiences and memories (Guntarik 2013). Meaningful engagement with, and formal recognition of, historical complexities and multiple past truths is critical in guiding society towards a future-orientated present.

The anxieties of the Australian administration in recognition of First Nations people ultimately hinder meaningful engagement with the past, as demonstrated by the planned 2020 nation-wide voyage of Captain Cook's Endeavour replica as a celebration of the 250th anniversary of his landing. The $\$ 6.7$ million dollar project is designed to share stories of Australia and educate society on the past (Macmillan 2019), however it is more likely to perpetuate binary narratives, further silence the stories of Aboriginal people and continue 
'producing a veil of comforting half-truths and lies' (Birch 2002, p. 42). Simultaneously, current public debate in Australia on Indigenous rights centres on the acknowledgement of historical truth and moving forward towards a model of reconciliation, culminating in the Uluru Statement from the Heart.

This essay will refer to a dense body of literature to look at the construction of Australia's national narrative, analyse Indigenous and non-Indigenous attempts at truth telling and critically examine the goal of reconciliation.

\section{Australia's National Narrative}

Prime Minister Scott Morrison's understanding of Captain Cook's voyage to the Australian coast as a 'legacy of science, exploration and reconciliation' (Hunter 2019) is a prime exhibit of the 'mythically creative and politically motivated process of history making' (Dorman 2016, p. 47). Cook's initial arrival on Dharawal land has historically been interpreted as either a 'meeting' or a 'contest' between two cultures, however these overly simplistic interpretations work to successfully mask the historical complexities in the 'British beginnings of the continent' (Nugent 2008, p. 198). In challenging these narratives, Nugent (2008) claims that the arrival of Captain Cook is better described as an equivocal eight-day encounter characterised by miscommunication, curiosity and fear and it is thus unfair to state that a 'meeting' between the two cultures ever occurred (Nugent 2008). Regardless of historical nuances, the encounter continues to be celebrated in the confines of historical truth as the nation's founding moment and refashioned as 'more than meeting and less than a clash' (Nugent 2008, p. 199). The rest of Australia's traditional historical narrative follows suit in rebranding a history of racist assimilationist ideologies as colonial saviour truths, ultimately positioning First Nations peoples in a historical camp between the 'civilised white' and the 'primitive black' (Birch 2002, p. 50).

In 1968, anthropologist W.E.H. Stanner used the term 'the Great Australian Silence' as a criticism of historians, academics and politicians alike for the omission of Aboriginal truths from their works (Stanner 1969). Consequently, a 'cult of forgetfulness' was forged by the promotion of 'a [particular] view from a [particular] window which has been carefully placed to exclude a whole quadrant of the landscape' (Stanner 1969, p. 24). The revelations of Stanner provided great impetus for the emergence of several counter-narratives, or 'small truths', that challenge the 'large truth' of nation making and ultimately usher Australia into an era of debate regarding historical truth that remains alive today (Read 2002; Curthoys 2008).

In the second half of the twentieth century revisionist historians, Aboriginal activists and academics undertook informal truth telling projects in seeking to uncover colonial silence and challenge the foundational narratives of the nation (Attwood 1994). A primary concern that emerged from these efforts was the idea of colonial violence being a crucial means for establishing dominance, ultimately challenging previous notions of settlement as a peaceful encounter (Attwood 1994). As noted by Attwood (1994, p. 119), "excessive and unrestrained 
violence was a key feature of European colonization - people were routinely shot, poisoned or beaten to death - but the violence, at one moment understood to be essential, was at a later moment denied or simply lost to [European] memory. This silence was a prescribed and accepted strategy and close to impenetrable". In this way, massacres evolved into being the prominent strategy used to eliminate Indigenous resistance to colonial efforts (Bunch 2018). In an effort to bring this into the public arena, academics, historians and archaeologists of the Newcastle University Frontier Massacres Project Team have undertaken The Massacre Map Project to map the truth behind massacres during the period of the 'frontier wars' (Bunch 2018). Currently in its third stage, the team has identified persistent and widespread colonial violence, having uncovered over 250 massacres and expecting the number to double (Bunch 2018). Out of these massacres it was revealed that ten of them correlated to higher coloniser fatality (The Guardian Australia n.a.). With this is mind, it is significant to consider the symbolic insensitivity of the federal government's intention of a commemorative voyage of the Endeavour to "offer insights into the 1770 journey and the experiences of Indigenous Australians" (Macmillan 2019).

Perhaps one of the most prominent truth telling projects in recent Australian history is The National Inquiry into the Separation of Aboriginal and Torres Strait Islander Children from their Families and its subsequent Bringing Them Home Report. In what is now recognised as the 'History Wars' (Dorman 2016), the trauma experienced by Aboriginal peoples resulting from forced removal policies became highly politicised and is often referred to as the cornerstone of contemporary Indigenous activism (Damousi 2002). As a truth commission, the inquiry sought to 'end denial about the impact, effects and extent of systematic and historical violence, challenging accepted understandings of the past by establishing a shared historical record of past violence and abuses' and as a result '(re)construct an official narrative of a country's violent and repressive past' in an effort to 'restore the national community' (Maddison 2019, p. 185). The report did not only achieve this through the testimonies and accounts of victims, but also outlined fifty-four recommendations to assist the healing process of Indigenous communities (Maddison 2019). Among these recommendations were a formal apology issued to First Nations people and financial compensation. The report was not well received by the Howard government, refusing apology and implementation of recommendations on the basis of denial (Maddison 2019). The current administrative context reflects the perception that the conservative ideology has seemingly transcended the context of the Howard government into contemporary society.

It is important to note that truth telling projects are not solely restricted to exploring the trauma of Indigenous populations. Politicians similarly engage in projects which attempt to reinforce a desired truth. As noted by historian Davison (2000, p. 57 cited in Nugent 2008, p. 200), "national commemorations use the events of history but the stories they tell are determined more by the politics of the present that the ideals of the past'. The historical truths a nation chooses to exemplify are evident in their treatment of the dead (Maddison 2019). The commemoration of Captain Cook through a replica voyage claims to catalyse open dialogue regarding Indigenous and colonial experiences of settlement to indicate the desire for reconciliation (Macmillan 2019), however it is more likely to perpetuate the glorified 
settler narrative in a way which does not adequately respect the historical truths of Indigenous experience. The paradoxical nature of the government's commemoration project brings into question the ultimate goal of reconciliation itself.

\section{The End Goal: Reconciliation}

When justice is sought in a restorative manner aimed at repairing damaged relationships, reconciliation emerges as a method of closure to past injustices (Cook \& Powell 2003). Reconciliation, defined as 'consisting of two-way relationships built on trust and respect, recognition and acceptance of rights, histories and cultures, and institutional and community support for all dimensions of reconciliation', is the 'espoused aspiration' of national governments and Aboriginal leaders (Palmer \& Pocock 2019, p. 1). Despite formal attempts at administering truth through policy, each attempt has been limited in their effectiveness due to the elusiveness of reconciliation and the cyclic nature of repression and resistance in the history of Australian public policy (Maddison 2019). Additionally, when examined through the lens of colonial ideology, reconciliation can be seen as yet another means of reinstating political authority over Indigenous people minus the violent repression of colonialism (Maddison 2019).

A decade after the release of the Bringing Them Home Report, a formal apology was issued to Indigenous people of the nation by the Rudd government (Cook \& Powell 2003). Despite Indigenous communities receiving formal acknowledgement on the national stage, the apology fell short of adequate acknowledgement of the trauma caused by colonial violence, Indigenous sovereignty to the land and offered no compensation for the acts of colonial violence during the Stolen Generations (Cook \& Powell 2003). Seeing as genuine acknowledgement is at the core of restorative justice, the 2008 apology is identified as a quick resolution to silence the increasing demands for recognition from Aboriginal activism. Australia is lodged in a cycle of repression and resistance which consists of Indigenous populations seeking open political debate on justice, colonial administrations responding with quick resolution policies that do not adequately acknowledge Indigenous autonomy and the public disappointment in the lack of effective policy driving further activism (Maddison 2019). The national government seeks reconciliation as a refuge from this cycle which has diminished the legitimacy of the settler narrative, however if it is not based on meaningful engagement with the past it is yet another manner in which settler colonial projects seek to silence Indigenous resistance (Maddison 2019). Whilst the settler state no longer directly pursues Indigenous deaths, the state continues to seek their social and political death (Maddison 2019). Furthermore, Indigenous populations do not feel their desires are adequately represented by the colonial pursuit of reconciliation (Palmer \& Pocock 2019). For reconciliation to be effective, Indigenous voice and truths must be central to policy.

In 2017, the Uluru Statement of the Heart was conceived by 250 Indigenous delegates of the Referendum Council to highlight the form in which meaningful change should occur in the nation (McKay 2017). Apart from a constitutionally enshrined First Nation Voice to parliament, the statement makes the prominent demand for a Makarrata truth telling body to 
instigate a dialogue of truth in the public and political sphere (Appleby \& Davis 2018). Whilst a First Nation voice to parliament ensures parliamentary protection and the inclusions of Indigenous culture in the founding body of the settler nation, a Makarrata commission offers peacemaking between sovereign nations of Indigenous and non-Indigenous Australia (Appleby \& Davis 2018).

In the context of historical truth, the Makarrata commission perhaps emerges as the more urgently significant demand in achieving larger structural reform that ensures society is able to understand the diverse truths and complexities of the national story and move forward (Appleby \& Davis 2018). The use of a Yolngu word indicates that this is a truth telling process that requires agreement 'within Australia, between Australians' (McKay 2017) and is further acknowledged as the dynamic work to heal injustices through Indigenous and nonIndigenous collaboration. Neither proposition seeks to alter the national narrative of the nation, they seek to provide a way meaningful change can be established through truth telling.

Parliamentary inaction in the implementation of The Uluru Statement of the Heart reflects the anxieties prevalent in Australian government bodies towards achieving productive reconciliation. The investment in the 2020 commemoration voyage of Captain Cook not only reflects the desire for society to remain comfortable under a 'veil of lies' (Birch 2002, p. 42), but also the preferred model of reconciliation that is being sought by policy.

\section{The Way Forward}

In the political and cultural debate of Australian history, it is important to consider colonial anxiety alongside Indigenous trauma. Contrasting to the words of former Prime Minister Paul Keating, 'valuable commodities, such as land, national identity and memory are at stake in the recognition of Indigenous sovereignty' (Birch 2002, p. 45).

The entirety of Australia's historical narrative is premised on colonial ideologies advocating for the elimination of difference in the name of white superiority, thus accepting uncomfortable truths as part of history would require a complete re-evaluation of the Australian psyche (Birch 2002, p. 45). Birch recognises that consequently the 'colonial view of history is upheld by conservative forces that in particular are able to prey on existing stereotypes of Aboriginal people, feeding a precondition to prejudice rather than recognising and attempting to overcome the nation's twin genealogies of dispossession and forgetfulness' (2002, p. 45). Truth telling processes do not aim for a single objective truth, but rather 'developing public understanding and deliberation about the different experiences of the society's history' (Appleby \& Davis 2018, p. 505) and moving towards a shared national narrative. 


\section{Conclusion}

In truth, we cannot confidently say that we have succeeded as we would like to have succeeded if we have not managed to extend opportunity and care, dignity and hope to the Indigenous people of Australia - the Aboriginal and Torres Strait Island people. (Keating 1992)

In contemporary society the traditional historical narrative of Australia is perceived as a fragile one wrought with injustice and binary tensions. Historians ought not to seek one ultimate truth of the past but rather an acceptance of diverse truths. Despite the fact that the history of European society in Australia constitutes less than $0.5 \%$ of the land's history (Attwood 1994, p. 121), the white colonial narrative dominates historical truth and further marginalises the already disproportionately disadvantaged Indigenous community. In alignment with this perception, the Australian administration ought to meaningfully engage with the nuances of the past to ensure a present day that is oriented towards national healing. Genuine acknowledgment and recognition of Indigenous sovereignty, a truth telling dialogue and the willing acceptance of uncomfortable truths constitute the pillars of productive reconciliation. A $\$ 6.7$ million project dedicated to commemorating the 'founding father' of the nation, and consequently generations of Indigenous repression, is not. 


\section{References}

Appleby, G. \& Davis, M. 2018, 'The Uluru Statement and the Promises of Truth', Australian Historical Studies, vol. 49, no. 4, pp. $501-509$.

Attwood, B. 1994, 'The Paradox of Australian Aboriginal History', Thesis Eleven, vol. 38, no. 1 , pp. $118-137$.

Birch, T. 2002, 'History is never bloodless' Getting it wrong after one hundred years of federation, Australian Historical Studies, vol. 33, no. 118, pp. 42 - 53.

Bunch, A. 2018, Colonial massacres to pass 500 mark: study, Sydney.

Cook, K. \& Powell, C. 2003, 'Unfinished business: Aboriginal reconciliation and restorative justice in Australia', Contemporary Justice Review,vol. 6, no. 3, pp. 279 - 291.

Curthoys, A. 2008, 'WEH Stanner and the historians', in Hinkson, M., and Beckett, J. (eds) An Appreciation of Difference: WEH Stanner and Aboriginal Australia, Canberra, Aboriginal Studies Press, pp 233-250.

Damousi, J. 2002, 'History matters: The politics of grief and injury in Australian history',Australian Historical Studies, vol. 33, no. 118, pp. 100 - 112.

Dorman, S. 2016, 'Drawing up a balance sheet: accounting for history in Australia', Continuum, vol. 30, no. 1, pp. 45 - 57.

Guntarik, O. 2013, “'Dangerous" Historiographies: Minoru Hokari's observations and lived Aboriginal practices of history', AlterNative: An International Journal of Indigenous Peoples, vol. 9, no. 1, pp. $30-44$.

Hunter, F. 2019, Endeavour replica to circumnavigate Australia for Cook anniversary, The Sydney Morning Herald, viewed 15 June, <https://www.smh.com.au/politics/federal/endeavour-replica-to-circumnavigate-australia-forcook-anniversary-20190121-p50sp2.html>.

Macmillan, J. 2019, Endeavour replica to sail around Australia to mark 250 years since Captain Cook's arrival, ABC News, viewed 14 June, $<$ https://www.abc.net.au/news/2019-01-22/endeavour-replica-to-sail-aroundaustralia/10734998>.

Maddison, S. 2019, 'The Limits of the Administration of Memory in Settler Colonial Societies: the Australian Case', International Journal of Politics, Culture, and Society, vol. 32, pp. $181-194$. 
McKay, D. 2017, 'Uluru Statement: A Quick Guide', Parliamentary Library, Department of Parliamentary Services, Canberra.

Nugent, M. 2008, 'The encounter between Captain Cook and Indigenous people at Botany Bay in 1770 reconsidered', in Veth, Sutton and Neale (eds) Strangers on the Shore: Early coastal Contacts in Australia, Canberra, National Museum of Australia Press, pp. 198-207.

Palmer, J. \& Pocock, C. 2019, 'Aboriginal colonial history and the (un)happy object of reconciliation’, Cultural Studies, pp. $1-17$.

Read, P. 2002, 'Clio or Janus? Historians and the Stolen Generations', Australian Historical Studies, vol. 33, no. 118, pp. $54-60$.

Redfern Speech (Year for the World's Indigenous People) - Delivered in Redfern Park by Prime Minister Paul Keating, 10 December 1992.

Stanner, W.E.H, 1969, 'The Great Australian Silence', The 1968 Boyer Lectures: After The Dreaming, Sydney, ABC Enterprises, pp. 18 - 29.

The Guardian Australia, n.a., The Killing Times, viewed 14 June, <https://www.theguardian.com/australia-news/ng-interactive/2019/mar/04/massacre-mapaustralia-the-killing-times-frontier-wars >. 